\title{
引抜き試験による異形鉄筋の付着強度に関する研究 STUDYS ON BOND STRENGTH OF DEFORMED BARS BY PULL-OUT TESTS
}

\author{
村田二郎*・河 合 糺 茲** \\ By Jiro MURATA and Tadashi KAWAI
}

\begin{abstract}
The properties of bond between reinforcing steel and concrete in a reinforced concrete structure are extremely complex, and an effective method of accurately testing bond strength has not yet been found. In this study are proposed a splitting and an eccentric pull-out test methods with a the principal aim to simulate the properties of bond failures of deformed bars. The former expresses the bond failure from splitting of concrete due to wedge actions of lugs of deformed bar, whil the latter expresses the bond failure due to shear of concrete between lugs of tension bars reinforced by lateral bars with short space, and detailed studies were made regarding shape and size of specimens, and procedures of testing in order that bonding performances can be satisfactorily tested.
\end{abstract}

\section{1. 緒言}

異形鉄筋の付着破壊は，ふしのくさび作用による鉄筋 周囲のコンクリートの割裂きに起因し，丸鋼のように鉄 筋とコンクリートとの界面の付着が切れ，滑動により抜 け出す現象とは全く相違する. しかし，異形鉄筋の付着 強度試験については，丸鋼常用時の試験方法がそのまま 適用されていたり，わずかな改良を加えた程度のものも 多く，根本的な検討が迫られている。

本来, 材料の力学特性の試験方法は, 試験値がそのま ま構造計算の資料として役立つことが望ましい.しかし， 構造物内の鉄筋とコンクリートとの付着性状は，鉄筋の 連続部や種々の端定着部によって応力状態が異なるばか りでなく, 鉄筋の表面形状やコンクリート強度はもちろ h, 鉄筋の間隔, かぶり厚さ, 横方向鉄筋の配置状態等 によっても影響されきわめて複雑であるから，理想的な 試験方法の確立は難しい。

最近, 内外で異形鉄筋の付着破壊機構に注目した試験

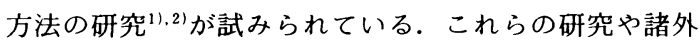

* 正会員 工博 東京都立大学教授 工学部土木工学科 ( ₹158 世田谷区深沢 2-1-1)

** 正会員 日本大学講師 生産工学部土木工学科 ( 于275 習志野市泉町 1-2-1)
国の規格等を参考にし，異形鉄筋の付着性状の特徵を表 現でき，少なくとも破壊のメカニズムは類似する簡易な 方法として，割裂き引抜き試験方法および偏心引抜き試 験方法を提案した。これらの方法は異形鉄筋およびコン クリートの付着に対する材料としての相対評価は可能と 思われる.

次に，丸鋼および市販の異形鉄筋を切削して，幾可学 的に規則性をもつふし形状および間隔を有する供試材を 作製し，上記の試験方法によって鉄筋の表面形状が付着 性状に及ぼす影響を確かめ, ふし形状や間隔の適正化に ついて論じた。 さらに，D 16〜D 57 の表面形状の異な る 5 種の市販の異形鉄筋について，これらの両試験を適 用し，国産異形鉄筋の付着特性を明らかにした。

\section{2. 使用材 料}

\section{（1）鉄筋}

実験に用いた鉄筋は，切削試験片と市販の異形鉄筋 5 種（高炬鉄筋）であって，材質はすべて SD 35 である. 切削試験片は，丸鎆および市販の横了し筋の加工品で あって，直径は D 32 に相当する. 丸鋼から切削した武 験片はふし間隔を直径の $0.5 \sim 3$ 倍，ふし高さを 2.2 $\mathrm{mm}$ としたものおよびふし側面の傾斜角を $15 \sim 90$ 度と したもので，幾何学的規則性をもっている. 市販品を加 
表一1試料鉄筋の機械的性質および表面形状

\begin{tabular}{|c|c|c|c|c|c|c|c|c|c|}
\hline 谈 & 㘯 & in & 的性 & 䇠 & 1 & 8 & 面 & 型 & 桨 \\
\hline 桐 & 乎80年 & 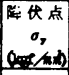 & 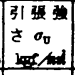 & \begin{tabular}{|c|} 
伸 \\
$(x)$
\end{tabular} & 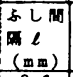 & 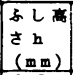 & 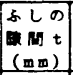 & 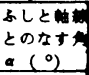 & 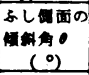 \\
\hline \multirow{8}{*}{ A } & D16 & 38. 2 & 57.2 & 26.8 & & 1. ${ }_{0}^{2}$ & 3.48 & 90.0 & 59.1 \\
\hline & D25 & 39.8 & 57.9 & 32.8 & & & & 90.0 & 57.0 \\
\hline & D32 & 40.6 & 57. 2 & 31.8 & & & & 90.0 & 54.0 \\
\hline & D35 & 40.4 & 57.3 & 29.3 & & & & 90.0 & 58.2 \\
\hline & D38 & 38.3 & 61.5 & 28.4 & & & & 90.0 & 57.4 \\
\hline & D41 & 41.6 & 62.6 & 24. 3 & & & & 90.0 & 58. 4 \\
\hline & DS1 & 41. 8 & 59. 7 & 21.4 & & & & 90.0 & 57. 2 \\
\hline & D57 & $\begin{array}{r}42.9 \\
\end{array}$ & 66.8 & \begin{tabular}{|l}
23.2 \\
\end{tabular} & & & & 90.0 & 44.3 \\
\hline \multirow{5}{*}{ B } & D32 & 39.6 & 57.1 & 29.6 & & & & 90.0 & 53.6 \\
\hline & D35 & 38. 2 & 57.8 & 28.3 & $\sqrt{12}$ & & & 90.0 & 57.2 \\
\hline & D38 & \begin{tabular}{|l}
37.8 \\
\end{tabular} & 59.6 & 28.4 & & & & 90.0 & 56.5 \\
\hline & D41 & 38.7 & 57.8 & 25.2 & & & & 90.0 & 58.3 \\
\hline & D51 & 38.4 & 58.1 & 24.4 & & & & 90.0 & 56.4 \\
\hline \multirow{4}{*}{ C } & D32 & 38.3 & 56. 2 & 27. 9 & & & & 90.0 & 58. 2 \\
\hline & D35 & \begin{tabular}{|l}
39.7 \\
\end{tabular} & 59.8 & 23.4 & & & & 90.0 & 54.2 \\
\hline & D38 & 37.3 & 55.4 & 22.2 & & (u. & & 90.0 & 54.3 \\
\hline & D51 & 39.2 & 57.2 & 25.1 & & & & 90.0 & 49.5 \\
\hline \multirow{7}{*}{ D } & D16 & 38.6 & 58.6 & 26.3 & $\begin{array}{l}10.4 \\
0.65\end{array}$ & & & 52.6 & 46. 1 \\
\hline & D25 & 39.1 & 60.7 & 27.5 & \begin{tabular}{|c|}
15.7 \\
0.628
\end{tabular} & $\begin{array}{ll}2 & 3 \\
0 & 0.9\end{array}$ & $\frac{1}{20}$ & 52. 7 & 48.4 \\
\hline & D32 & 39.4 & 611 & 280 & & & & 53. 8 & 44.0 \\
\hline & D35 & 38.3 & 57.2 & 29.1 & $\begin{array}{l}23.6 \\
0.68) \\
\end{array}$ & & & 53.6 & 49. 7 \\
\hline & D38 & 38.2 & 57.6 & 28.4 & $\begin{array}{l}25.8 \\
0.68)\end{array}$ & & & 53.5 & 50.3 \\
\hline & D41 & 36.4 & 58.0 & 22.3 & & 2) & & 71.1 & 52.3 \\
\hline & D51 & 38.3 & 56.4 & 26.6 & $\begin{array}{l}30.1 \\
0.59)\end{array}$ & $\begin{array}{l}4.6 \\
0.09)\end{array}$ & & 72.5 & 53. 6 \\
\hline \multirow{5}{*}{$\mathrm{E}$} & D32 & 38.7 & 57.8 & 28.1 & 8. 512 & 2.87 & (0: $\left.1^{8}\right)$ & 52. 8 & 48.3 \\
\hline & D35 & 39.6 & 58.9 & 27.4 & $\begin{array}{l}20.0 \\
0.57\end{array}$ & $\begin{array}{l}2.2 \\
0.06)\end{array}$ & $\begin{array}{l}6.2 \\
0.18)\end{array}$ & 53.1 & 48. 9 \\
\hline & D38 & 38.2 & 56.2 & 24.3 & $\begin{array}{l}23.4 \\
0.61 \\
\end{array}$ & $\begin{array}{l}2.4 \\
(0.06)\end{array}$ & & 52.8 & 49. 7 \\
\hline & D41 & 37.4 & 57.8 & 25.2 & $\left.\begin{array}{c}25.7 \\
0.62\end{array}\right]$ & $\left.\begin{array}{ll}3.0 \\
0 & 0\end{array}\right]$ & $\begin{array}{l}7.8 \\
0.19)\end{array}$ & 52.5 & 51.1 \\
\hline & D51 & 38. 3 & 59.6 & 23.3 & $\begin{array}{l}32.1 \\
0,637\end{array}$ & \begin{tabular}{|ll}
4.5 & 5 \\
0. & 099
\end{tabular} & 8. 517 & 75.1 & 53. 2 \\
\hline
\end{tabular}

エしたものは横ふし筋のふしを 1 個おきおよび 3 個中 2 個を切除したもの，ふし高さを $1 / 3 \sim 2 / 3$ に切削したも のである. 市販の異形鉄筋は, 横ふし筋 3 種と斜めふし 筋 2 種であって，寸法はD 16〜D 57 である。これらの 機械的性質および表面形状を表一1に示す．表一1にお いて，大部分の鉄筋のふし間隔および高さは直径にほぼ 比例しているが，鉄筋 B および E の D 51, 鉄筋 D の $\mathrm{D} 41$ 以上は, ふし間隔を特に短縮しており，鉄筋 $\mathrm{A} の$ D 16 および D 57 以外は, ふし間隔を $15 \mathrm{~mm}$ の定值と している．なお，表一1に示すふし側面の傾斜角は鉄筋 の軸を含む面で切断し，断面を撮影し拡大した印画上で 測定したものである.

\section{（2）コンクリート}

コンクリートは, 粗骨材の最大寸法を $20 \mathrm{~mm}$ および $25 \mathrm{~mm}$ ，スランプ約 $8 \mathrm{~cm}$, 材令 28 日の圧縮強度約 300 $\mathrm{kgf} / \mathrm{cm}^{2}$ のものとした。 ただし、コンクリート強度の影 響を試験するために，圧縮強度約 200，250，350 および $400 \mathrm{kgf} / \mathrm{cm}^{2}$ のコンクリートも用いた。これらの配合を 表一2に示す．使用したセメントは，日本社製普通ポル トランドセメントおよび早強ポルトランドセメント, 細 粗骨材は富士川産の川砂および川砂利である.
表一2 コンクリートの配合

\begin{tabular}{|c|c|c|c|c|c|c|c|c|}
\hline コンクリ & 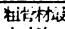 & スランフ & 水七メン & 細解楼 & 监 位 & 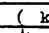 & II") & \\
\hline 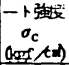 & $\begin{array}{c}\text { 大寸法 } \\
G_{\text {m.x }} \\
(\mathrm{mm})\end{array}$ & 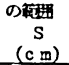 & $\begin{array}{l}\text { 1比 } \\
W / C \\
(\Phi)\end{array}$ & $\begin{array}{c}\mathrm{s} / \mathrm{a} \\
(\mathrm{p})\end{array}$ & $\begin{array}{c}t \times y+ \\
c\end{array}$ & $\begin{array}{l}\text { 永 } \\
\text { W }\end{array}$ & S & $\begin{array}{c}\text { 名利 } \\
a\end{array}$ \\
\hline 200 & 25 & $8 \pm 2$ & 63 & 42 & 284 & 179 & 774 & 106 \\
\hline 250 & $\overline{25}$ & 42 & 63 & 41 & 292 & 175 & 738 & 107 \\
\hline 300 & 20 & 2 & 55 & 40 & 300 & 170 & 738 & 1140 \\
\hline 300 & 2 & & 58 & 41 & 297 & 172 & 758 & 10 \\
\hline 350 & 25 & $8+2$ & 55 & 41 & 300 & 169 & 770 & \pm \\
\hline 400 & 25 & $\approx$ & 53 & 40 & 31 & 167 & 739 & 1108 \\
\hline 450 & 25 & $8+2$ & 50 & 39 & 330 & 165 & 700 & 1] \\
\hline
\end{tabular}

\section{3. 割裂き引抜き試験}

\section{（1）試験方法}

通常のかぶりを有する鉄筋コンクリート部材における 異形鉄筋の付着破壊は，ふしのくさび作用に起因するコ ンクリートの割裂きによるから，鉄筋に沿う縦ひびわれ 発生時の付着強度は付着性能評価の重要な尺度となる。 ひびわれ発生時の付着強度を容易に求めるために, 無補 強コンクリート供試体からの鉄筋の引抜き試験を採用 し，割裂き引抜き試験と名付けた。無補強コンクリート 供試体による引抜き試験として, 従来 ASTM C 234 ${ }^{31}$, RILEM 暫定規準4)等の方法があるが，前者は丸鋼に対 して考案されたものをそのまま異形鉄筋にも適用してい るのであり，後者はコンクリートの割裂きが生じないよ う供試体の一辺を鉄筋直径の 10 倍としたものであって, いずれも本試験方法とは基本的に相違する.

\section{a）供試体の形状および寸法}

割裂き引抜き試験における最大引抜き力は, コンク リート供試体の割裂荷重にほかならないから，鉄筋直径 の影響を消去するために供試体各部の寸法を鉄筋直径に 正しく比例させる必要がある. そこで，一辺を鉄筋直径 の 6 倍（以下 $6 \phi$ と記す），8 $\phi$ および $10 \phi$ とした立方 形供試体による引抜き試験を行い，供武体の形状および 寸法について検討した。 この場合, よ゙の供試体も加圧板 からの応力の均等化を図るために荷重端側に長さ $2 \phi$ の 非付着区間を設けた，試験の結果を図一1に示す，図一 1 において，一辺を $10 \phi$ とした場合は，コンクリート の破壊以前に鉄筋が破断することが多いが，6申または $8 \phi$ とした場合は, 付着応力すべり関係, 割裂き付着強 度等に本質的な差異は認められないので，太径鉄筋への 適用も考慮して一辺を $6 \phi$ と定めた。

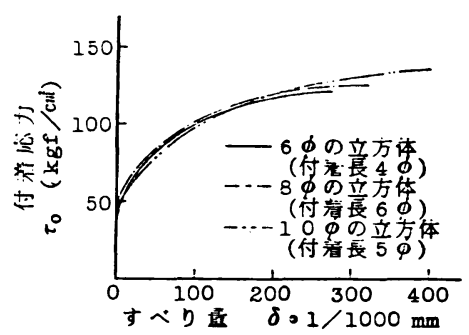

図一1 供試体寸法が付着強度に及ぼす影需 
表一3 非付着区間の有無による付㴋強度試験值のばらつき

\begin{tabular}{|c|c|c|c|c|c|c|c|}
\hline $\begin{array}{l}\text { セメント } \\
\text { の種面 }\end{array}$ & 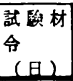 & $\begin{array}{l}\text { 非付着 } \\
\text { 区間の } \\
\text { 直算 }\end{array}$ & $\begin{array}{l}\text { 供言体 } \\
\text { 数 } \\
(\text { 体) } \\
\end{array}$ & 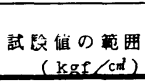 & $\begin{array}{l}\text { 平均值 } \\
0 \mathrm{sg} \in(\mathrm{m})\end{array}$ & 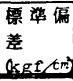 & \begin{tabular}{|c|} 
変勤係 \\
数 \\
$(\%)$ \\
\end{tabular} \\
\hline \multirow[b]{2}{*}{ 普通 } & \multirow[b]{2}{*}{14} & 有 & 10 & $120 \sim 134$ & 124 & 3.97 & 3.2 \\
\hline & & E & 10 & $117 \sim 147$ & 133 & 9.26 & 7.0 \\
\hline \multirow{3}{*}{ 普通 } & \multirow{3}{*}{28} & 直 & 10 & $120 \sim 131$ & 126 & 3.21 & 25 \\
\hline & & 監 & 10 & $125 \sim 155$ & 139 & 10.30 & 7.4 \\
\hline & & 無 & 10 & $98 \sim 123$ & 109 & 10.50 & 9.6 \\
\hline \multirow[b]{2}{*}{ 早㤝 } & \multirow[b]{2}{*}{14} & 直 & 10 & $121 \sim 133$ & 125 & 3. 50 & 28 \\
\hline & & 無 \% & 10 & $127 \sim 158$ & 137 & 10.00 & 7.3 \\
\hline
\end{tabular}

注）※印はテフロンシートを挿入したものである。

付者長は、非付薏区間のあるものは $4 \phi$ 、非付㩰区問のないものは $6 \phi$ である。 使用鉄筋は、㰸筋AのD 32 である。

表一3 は, 一辺 $6 \phi$ 立方形供試体において, 荷重端 側に非付着区間を設けた場合と設けない場合の付着強度 試験值のばらつきを比較したものである．表一3におい て, 非付着区間のない場合の試験值の変動係数は約 10 $\%$ となり，供試体と加圧板との間にテフロンシートを 插入した場合でも，変動係数は $7.0 〜 7.4 \%$ となってい る.これに対し，非付着区間のある場合は，変動係数は $2.5 \sim 3.2 \%$ であって，非付着区間の設定は試験誤差の 低減に有効であるとともに，供試体の補強部として作用 し, 割裂き付着強度を高め, 比較的広い範囲の付着応力 すべり関係を与えることができる．このように，非付着 区間は補強部として動くから，鉄筋が通る孔径も鉄筋直 径に比例させる必要がある。このため，JIS K 6771 「軟 質ビニール管」に規定する塩化ビニール管から，その内 径が鉄筋外径にほぼ等しいものを選んで鉄筋を被覆すれ ば, 孔径と鉄筋直径亡の比を $1.2 \sim 1.5$ とすることがで きる.なお，自由端側のコンクリートに引張応力が生じ ることから，自由端にも非付着区間を設けるのがよいと の研究 ${ }^{5}$ もあるが, 供試体の製作が繁雑となるため, 荷 重端側だけに設けることとした。

次に，一辺 $4 \phi, 6 \phi, 8 \phi$ および $10 \phi$ の正方形断面, 高さを $4 \phi$ とした供試体（非付着区間なし）について， かぶり厚さが付着強度に及ぼす影響を試験した。試験の 結果は表一4のようであって，かぶりが鉄筋直径の 4.5 倍程度までは, 破壊時においてコンクリートに働くフー プテンションのかぶり方向における平均的な值はほぼ一 定と考えられる.

b）供試体の製造および養生

側板に鉄筋を通す開口部を設けた型枠に鉄筋を水平に

\section{表一4かぶり厚さが割裂き付㴋強度に及ぼす影的}

\begin{tabular}{|c|c|c|c|}
\hline $\begin{array}{l}\text { 供弪体听面 } \\
\text { の一辺の長 } \\
\text { さ } \ell(\phi)\end{array}$ & $\begin{array}{c}\text { かふり厚さ } \\
\mathrm{t} \\
(\mathrm{cm})\end{array}$ & $\begin{array}{l}\text { 割裂き付亲強 } \\
\text { 度 } \tau_{\mathrm{os}} \\
\left(\mathrm{kgf} / \mathrm{cm}^{\mathrm{l}}\right)\end{array}$ & $\begin{array}{l}\tau_{\mathrm{os}} / \mathrm{t} \\
\left(\mathrm{kgf} / \mathrm{cm}^{2} / \mathrm{cm}\right)\end{array}$ \\
\hline 4 & $4.8 \quad(1.5 \phi)$ & 70 & 16.7 \\
\hline 6 & $8.0 \quad(2.5 \phi)$ & 124 & -49.6 \\
\hline 8 & $11.1 \quad(3.5 \phi)$ & 170 & 48.6 \\
\hline 10 & 14.3 & 208 & \\
\hline
\end{tabular}

注) 铁徐 A D 32 使用。
設置する．この場合，付着区間となる部分は，文字など の圧延マークのない部分とし，あらかじめ十分に清掃し た。コンクリートは, 厚さ $10 \mathrm{~cm}$ 以下のほぼ相等しい 層に分けて打ち込み，各層を小型内部振動機を用いて締 め固め，上面を平滑に仕上げた，同時にJIS A 1132 に 従い, $\phi 10 \times 20 \mathrm{~cm}$ 圧縮強度試験供試体を作製した。供 試体の養生は，材令 2 日で脱型し， $20 \pm 2{ }^{\circ} \mathrm{C}$ の水中で養 生し，材令 28 日において試験を行った。

c）載荷方法および試験結果の表わし方

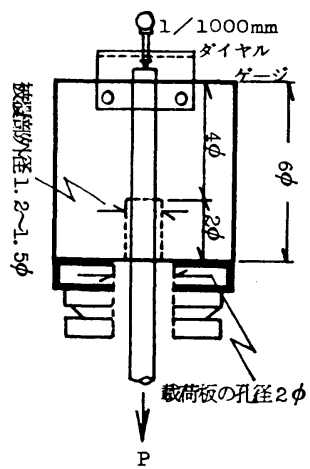

\section{図一2 割裂き引抜き試験供試体および載荷状況}

載荷方法は図一2に示すように，鉄筋直径の約 2 倍の 孔径を有する加圧板上に湿潤状態の供試体を正しく据 え，球座を介して鉄筋に引張力を与えた．鉄筋のすべり 量は, 自由端に設置した $1 / 1000 \mathrm{~mm}$ ダイヤルゲージに よって測定した. 荷重速度は, 鉄筋の引張応力の増加が 毎分 $500 \mathrm{kgf} / \mathrm{cm}^{2}$ 以下とし, 自由端すべり量 $0.01 \sim 0.1$ $\mathrm{mm}$ の範囲で適当な間隔で荷重を読み取り，式（1）を 用い, 各すべり量における付着応力を計算した。

$$
\tau_{0}=\frac{P}{4 \pi \phi^{2}} \cdot \alpha
$$

ここに, $\tau_{0}$ : 付着応力 $\left(\mathrm{kgf} / \mathrm{cm}^{2}\right), P$ : 引張力 $(\mathrm{kgf})$, $\phi:$ 鉄筋の公称直径 $(\mathrm{cm}), \alpha$ : 補正係数 $\left\{\alpha=300 / \sigma_{c}, \sigma_{c}\right.$ は同時に造った円柱供試体の圧縮強度 $\left.\left(\mathrm{kgf} / \mathrm{cm}^{2}\right)\right\}$.

$\alpha$ は, 目標強度からの若干の差異に対する補正係数で あって, 圧縮強度 $300 \mathrm{kgf} / \mathrm{cm}^{2}$ の場合を基準としている. この值は後述するように，圧縮強度約 $200 \sim 400$ $\mathrm{kgf} / \mathrm{cm}^{2}$ の範囲で割裂き付着強度は圧縮強度にほぼ一次 比例することから定めたのであって，RILEM の暫定規 準神においても同様な補正係数を用いている.

式（1）功求めた付着応力を用い, 付着応力すべり 曲線を描くとともに，割裂き付着強度 $\tau_{0 s}$ および鉄筋直 径の $0.2 \%$ に相当するすべり量における付着応力を計 算し, 初期付着強度 $\tau_{0 i}$ とした. 


\section{（2）異形鉄筋の表面形状が割裂き付着強度に及ぼす 影紫}

a）ふし側面の傾斜角の影響

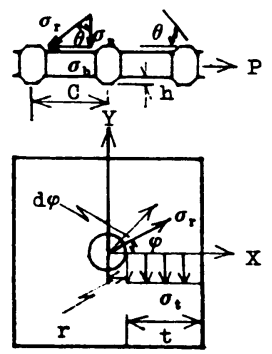

図一3 異形鉄筋のくさび作用

かぶりコンクリートの割裂きは図一 3 に示すように， ふしに働く支圧応力の水平分力に等しい半径方向忘力に 起因するフープテンションによる. フープテンションが ふし間隔およびかぶりの方向に一様に分布すると仮定す れば, その大きさは式 (2) で与えられる.

$$
\begin{aligned}
& \sigma_{t}=\frac{1}{c t} \int_{0}^{\pi / 2} h \cdot \sigma_{b} \cdot \cot \theta \cdot \sin \varphi \cdot r d \varphi \\
& =\frac{h r}{c t} \cdot \sigma_{b} \cdot \cot \theta
\end{aligned}
$$

ここに, $\sigma_{t}$ : フープテンション $\left(\mathrm{kgf} / \mathrm{cm}^{2}\right), \sigma_{b}$ : 支圧応 力 $\left(\mathrm{kgf} / \mathrm{cm}^{2}\right), c:$ ふ しの間隔 $(\mathrm{cm}), h:$ ふ $h$ し高さ $(\mathrm{cm})$, $\theta:$ ふ 儿側面の傾斜角 (度), $r$ : 鉄筋の半径 $(\mathrm{cm}), t$ :かぶり $(\mathrm{cm})$.

異形鉄筋の付着応力は, ふしの支圧応力, 鉄筋とコン クリートとの接着力および摩擦力からなっているが，後 二者は前者に比べて小さいのでこれを無視し，かつ付着 応力は鉄筋の長さに沿って一様に分布すると仮定すれ ば,

$$
\tau_{0}=\frac{h}{c} \cdot \sigma_{b}=\frac{2 t}{\phi} \cdot \sigma_{t} \cdot \tan \theta
$$

$t / \phi=\gamma$ とおけば，割裂き付着強度は，

$$
\tau_{0 s}=\gamma \cdot \sigma_{t u} \tan \theta=
$$

ここに, $\tau_{0 s}$ ：割裂き付着強度 $\left(\mathrm{kgf} / \mathrm{cm}^{2}\right), \sigma_{t u}$ : コンクリー 卜の引張強度 $\left(\mathrm{kgf} / \mathrm{cm}^{2}\right)$.

したがって，フープテンションがふしの間隔およびか ぶり方向に一様に分布すると仮定できる場合には，割裂 き付着強度は式(4) で与えられ, かぶり厚さと鉄筋直 径とが定比の場合には，コンクリートの引張強度とふし 側面の傾斜角だけに関係する. 本研究で選定した供試体 では $\gamma=2.5$ である.

ふしし側面の傾斜角と割裂き付着強度 $\tau_{0 s}$ の関係を実験 によって確かめるために丸鋼を切削し，ふし間隔 22 $\mathrm{mm}$ ，ふし高さ $2.2 \mathrm{~mm}$ ，ふしし側面の傾斜角を $15 \sim 90$ 度

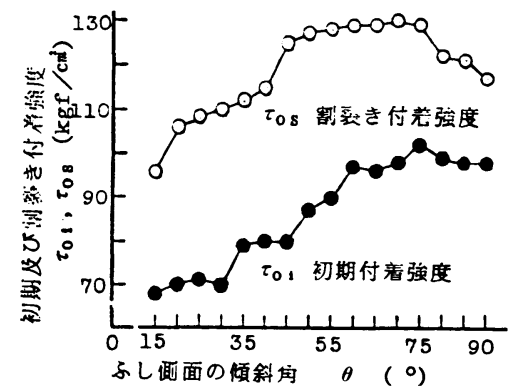

図一4 ふし側面の傾斜角が初期および割裂き付着強度 に及ぼす影标

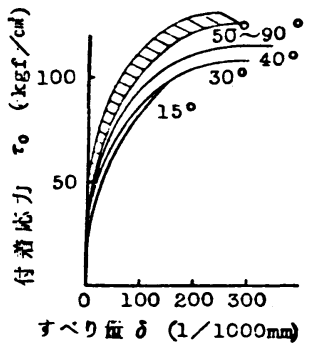

\section{図一5 ふし側面の傾斜角差異が付着応力すべり曲線に 及ぼす影}

まで 5 度おきに変化させた D 32 の横ふし形モデル鉄筋 を製作した。このモデル鉄筋を用いた割裂き引抜き試験 結果を図一 4 に示す。図一 4 において，ふし側面の傾斜 角が 45 度程度以下の場合は, 傾斜角が増すほど割裂き 付着強度は増大する。そ増大する程度は 92 から 125 $\mathrm{kgf} / \mathrm{cm}^{2}$ であって, 必ずしも $\tan \theta$ に一次比例しないが, これは, 非付着区間による補強の影響と思われる. 傾斜 角が 45 度を超えると割裂き付着強度はあまり変化せず, $130 \mathrm{kgf} / \mathrm{cm}^{2}$ 前後となっている.これは, 傾斜角が小さ い場合は，ふしの斜面に沿って鉄筋が滑り，コンクリー 卜を押し広げるように㗢くが，傾斜角が 45 度以上にな ると,ふし前面のモルタルが局部支圧によって粉状化し, 鉄筋がわずかに移動し，さらに，押し固められた粉状の モルタルは 30〜40 度の傾斜をもつふしと同様に作用し て割裂き作用が進行するといわれている ${ }^{61.7)}$. 図一5は, ふし側面の傾斜角が 45 度より小さい場合と大きい場合 の典型的な付着応力すべり曲線であって, 上記の考察を 裏付けている。なお，初期付着強度に及ぼすふし側面の 傾斜角の影響はより䫓著であって，図一5に示すように 60 70 度程度まで傾斜角の増加に伴って初期付着強度 は増大する．したがって，異形鉄筋のふし側面の傾斜角 は少なくとも 45 度以上とするのが適当と思われる.

b) ふし間隔の影響

丸鋼を切削し，ふし間隔を変化させた D 32 の横ふし 


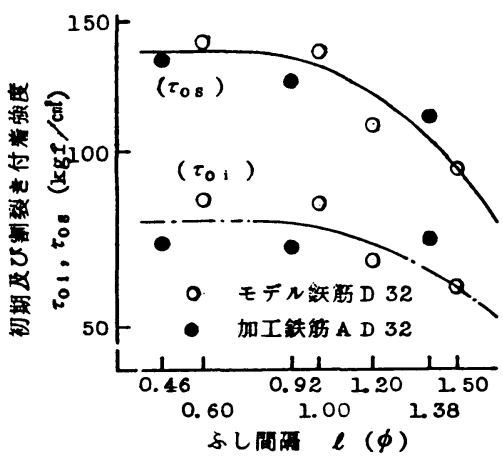

図一6 割裂き引抜き試験によるふし間隔が初期および 割裂き付着強度に及ぼす影要

形モデル鉄筋と D 32 の鉄筋 A のふしを適宜切除したも のについて割裂き引抜き試験を行った。モデル鉄筋のふ し間隔は, $19.0 \mathrm{~mm}(0.6 \phi), 31.8 \mathrm{~mm}(1 \phi), 38.2 \mathrm{~mm}$ $(1.2 \phi)$ および $47.9 \mathrm{~mm}(1.5 \phi)$, ふし高さ $2.2 \mathrm{~mm}$, 了し側面の傾斜角 90 度である. 鉄筋 A の加工品は, 了, しを 1 個おきおよび 3 個中 2 個を切除したもので，ふし 間隔 $14.6 \mathrm{~mm}(0.46 \phi), 29.3 \mathrm{~mm}(0.92 \phi)$ および $43.9 \mathrm{~mm}(1.38 \phi)$, ふし高さ $2.2 \mathrm{~mm}$, ふし側面の傾斜 角約 57 度である.

試験の結果を図一6に示す. 図一6において，モデル 鉄筋と鉄筋 A の加工品とで実験結果に大差なく, 割裂 き付着強度は，ふし間隔が鉄筋直径以下の場合同等であ るが，鉄筋直径を超えるとしだいに減少し，鉄筋直径の 1.5 倍の場合約 $12 \%$ 減少した。これは, ふし間隔が増 大するとふしの支圧応力によるフープテンションがふし 近傍に集中するためであって，フープテンションがふし 間隔に一様に分布するとみなし得るのは，ふし間隔がお よそ鉄筋直径以下の場合であることを示唆している.な お，ふし間隔が初期付着強度に及ぼす影響は，ふし間コ ンクリートが弾性状態に近いため, 割裂き付着強度の場 合より緩和されると考えられる。したがって，異形鉄筋 のふし間隔は, 割裂き破壊の観点からは, その直径以下 とするのが適当である.

\section{c) ふし高さの影響}

丸鋼を切削して D 32 の横ふし形モデル鉄筋を製作 し, ふし高さ $1 \mathrm{~mm}, 1.5 \mathrm{~mm}, 2 \mathrm{~mm}$ および $2.5 \mathrm{~mm}(0.03$ $\sim 0.08 \phi)$ ， 了し間隔 $22 \mathrm{~mm}$ ， 了し側面の傾斜角を 90 度としたものおよび D 32 の鉄筋 A のふし高さを $1 / 3$, $1 / 2$ および $2 / 3(0.73 \sim 1.47 \mathrm{~mm})$ に切削したものにつ いて割裂き引抜き試験を行った。試験結果を図一7に示 す.式（4）において，ふし高さは割裂き付着強度に影 響しないことになる.しかし，図一7においては，ふし 高さが鉄筋直径の約 $8 \%$ 程度以下の範用では, モデル鉄 筋の場合, ふし高さに比例して $17 \mathrm{kgf} / \mathrm{cm}^{2}$ 程度ではあ

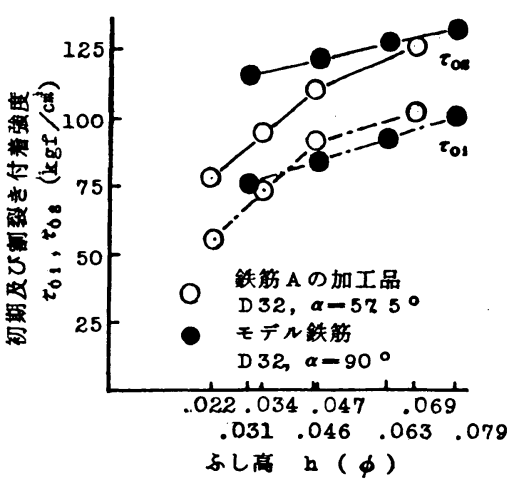

図一7 ふし高が初期および割裂き付㴋強度に及ぼす影

るが割裂き付着強度は增大している．鉄筋 A の加工品 の場合，モデル鉄筋と同様な傾向を示さなかったのは， ふしし頂部を切削して所定の高さとしたので，ふし高さ が低いものほどふし側面の平均的な勾配が緩やかとなっ たためと思われる. ふし高さは初期付着強度の増加に有 効であり，ある範囲内でなるべく高くするのが有利であ る. 通常の引抜き試験の結果において，ふし高さが直径 の $7 \%$ 程度までは付着強度は，ふし高さに伴って増大す るが $7 \%$ を超えると減少する傾向を示した研究 ${ }^{81}$ もあ る.

\section{（３）コンクリート強度が割裂き付着強度に及ぼす影}

図一8は，圧縮強度約 $200 ， 250 ， 300 ， 350$ および 400 $\mathrm{kgf} / \mathrm{cm}^{2}$ のコンクリートを用い, コンクリート強度と割 裂き付着強度との関係を試験した結果である.なお，使 用鉄筋はD 32 の鉄筋 A である. 図一8において, 割裂 き付着強度は, 圧縮強度の増加に伴いほぼ直線的に増大 することが認められる.したがって，コンクリートの圧 縮強度が $200 \sim 400 \mathrm{kgf} / \mathrm{cm}^{2}$ の範囲では, 割裂き付着強 度は圧縮強度に一次比例するとみなしてよい。式（1） 中の補正係数 $\alpha$ は, この実験結果に基づいて定めたの である。

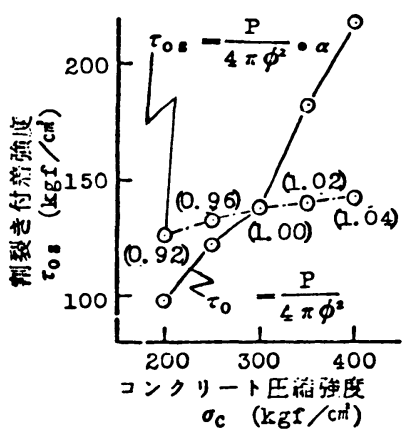

図一8 浦正係数 $\alpha$ に関する実唉結果 


\section{4. 偏心引抜き試験}

\section{（1）試䀦方法}

異形鉄筋の付着破壊は, 一般にかぶりコンクリートの 割裂きに起因するが，部材内の軸方向鉄筋は通常横方向 鉄筋で十分に取り囲まれているので，鉄筋に沿う縦ひび われの発生によってただちに付着耐力を失うことはな い. かぶりが特に大きい場合は別として, 荷重の増加に よって縦ひびわれがしだいに開口するとともに鉄筋が移 動し，ついに，ふし間コンクリートのせん断破壊によっ て鉄筋が引き抜け，付着の終局状態亡なる。このような 終局付着強度を試験するための方法として, RILEM の 暫定規準 ${ }^{9)}$ を参考にし，はりのせん断スパン部をモデル 化した偏心引抜き試験方法を提案した。

a) 供試体の形状および寸法

供試体の形状および寸法を図一9に示す。供試体は, はりの下縁に引張鉄筋を配置し，スターラップで十分補 強したものであって, 図中に示す荷重, 反力の作用点お よび作用方向によって, 供試体は, はりのせん断スパン 部を表現している．供試体各部の寸法は，鉄筋直径に比 例しており, 幅 $6 \phi$, 高さ $8 \phi$ の長方形断面で, 全長は $16 \phi$ となっている.

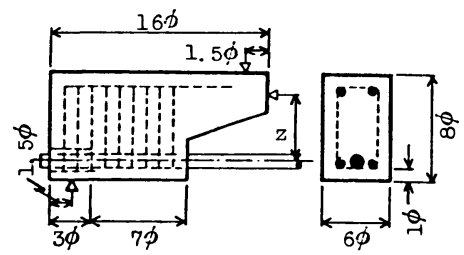

図一9 偏心引抜き供試体

軸方向鉄筋のかぶりは $1 \phi$ とした。これは，早期に鉄 筋に沿う縦ひびわれが発生し，しだいに付着破壊が進行 する状態を再現するためであって，D 32 の鉄筋 A およ びDを用い，かぶりを $1 \phi, 1.5 \phi$ および $2 \phi$ として偏 心引抜き試験を行った結果，縦ひびわれ発生荷重はかぶ りが 1 фの場合, 終局荷重の 15 20\%であるのに対し, 1.5〜2 ○の場合は 85〜95\%となったからである.ただ し,スターラップで十分補強してあるため, かぶりによっ て終局付着強度に差異は少なく，たとえば，鉄筋 A を 用いた場合かぶりが $1 \phi, 1.5 \phi$ および $2 \phi に$ 対し，終 局付着強度は，それぞれ約 $71 \mathrm{kgf} / \mathrm{cm}^{2}, 77 \mathrm{kgf} / \mathrm{cm}^{2}$ お よび $77 \mathrm{kgf} / \mathrm{cm}^{2}$ であった。

次に，軸方向鉄筋の付着強度に及ぼす支点反力の影響 を消去するために，支点付近の付着を断ち，付着長は 7 фとした.このため, 供試体は支点付近で無筋コンクリー 卜となり，早期にひびわれが発生し，斜めひびわれに発 展しやすい，斜めひびわれが軸方向鉄筋の付着性状に及
ぼす影響を極力低減するために，せん断応力が比較的小 さいはり形状とするとともに，スターラップを密に配置 し，さらに，はり下側のスターラップの隅角部に比較的 太い組立て鉄筋を配置し，これを支点付近における引張 鉄筋として作用させた。

鉄筋の引張応力に対するコンクリートのせん断応力の 割合は, $S a=T z$ より,

$$
\xi=\frac{\tau}{\sigma_{s}}=\frac{S}{b d} \cdot \frac{A_{s} \cdot z}{M}=\frac{A_{s}}{b d} \cdot \frac{z}{a}
$$

ここに, $S$ : はりのせん断力 $(\mathrm{kgf}), T$ : 鉄筋の引張力 $(\mathrm{kgf}), \tau$ : 平均せん断応力 $\left(\mathrm{kgf} / \mathrm{cm}^{2}\right), \sigma_{s}$ : 鉄筋の引 張応力 $\left(\mathrm{kgf} / \mathrm{cm}^{2}\right), b$ : 供試体幅 $(\mathrm{cm}), d$ : 有効高さ $(\mathrm{cm}), A_{s}$ : 鉄筋断面積 $\left(\mathrm{cm}^{2}\right), z:$ ア $\boldsymbol{z}$ 長 $(\mathrm{cm})$, $M$ : 曲げモーメント $(\mathrm{kg} \cdot \mathrm{cm}), a$ : せん断スパン $(\mathrm{cm})$. ここで, $b=6 \phi, d=6.5 \phi, a=13 \phi$, ヤング係数比 $n$ $=7$ として, $\xi \fallingdotseq 0.01$ である.

スターラップは, D 10〜D 25 を 3〜 $5 \mathrm{~cm}$ 間隔に配置 した。 スターラップ量を $a_{s} / A_{s} \cdot s$ で表わせば 0.012 $0.014 \mathrm{~cm}^{-1}$ となっている. ただし， $a_{s}:$ スターラップ 本の断面積 $\left(\mathrm{cm}^{2}\right), s$ : スターラップの間隔 $(\mathrm{cm})$, スター ラップ比で表わせば特例を除き，0.94〜1.24\%であっ て, 前記の理由により通常の鉄筋コンクリートは, はり の場合より著しく大となっている.

次に組立て鉄筋として軸方向鉄筋の直径の約 $1 / 3$ およ び約 $1 / 2$ のものを用い, 斜めひびわれ発生状況を検討し た結果，軸方向鉄筋が D 32 の場合もD 51 の場合も組 立て鉄筋の直径を軸方向鉄筋の約 $1 / 3$ および約 $1 / 2$ とし た場合，斜めひびわれはそれぞれ終局荷重の約 $80 \%$ お よび $90 \%$ 付近で発生した。この実験結果に基づいて, 軸方向鉄筋の約 $1 / 2$ の直径を有する組立て鉄筋を用いる こととした。

b）供試体の製造および養生方法

引張鉄筋をスターラップと組立て鉄筋を用いて型枠内 の所定位置に正しく配置し, 支点上の引張鉄筋の非付着 区間を塩化ビニール管で被覆した．引張鉄筋を下側にし てコンクリートを 2 層に打ち込み，各層を小型内部振動 機を用いて締め固めた．同時に， $\phi 10 \times 20 \mathrm{~cm}$ 圧縮強度 試験供試体を作製した。これらの供試体は材令 2 日で脱 型し, 温度 $20 \pm 1^{\circ} \mathrm{C}$, 湿度 $90 \pm 5 \%$ の蓩室内で養生し, 材令 28 日において試験を行った。

c) 載荷方法

載荷は, 図一10および図一11に示す載荷装置を用い て行った. 図一10は万能試験機に載荷枠を取り付けた もので，試料鉄筋が D 32 以下の場合に適用し，D 32 を 超える場合は，図一11 の特殊載荷装置を用いた。

載荷は, 試料鉄筋に引張力を与え, その反力を支点 $\mathrm{A}$, $\mathrm{B}$ および Cで受ける.なお，この場合供試体の底面を 

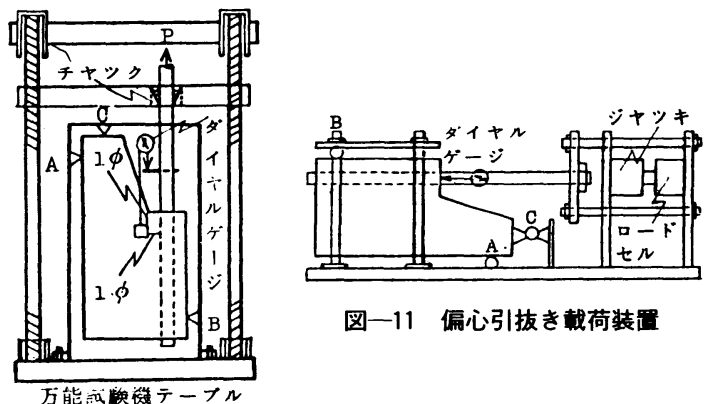

図一11 偏心引抜き载荷装置

\section{図一10 偏心引抜き载荷装重}

上側にして設置し，ひびわれが容易に観察できるように した. 荷重速度は, 鉄筋の引張応力の増加が毎分 500 $\mathrm{kgf} / \mathrm{cm}^{2}$ 以下となるようにした. 鉄筋の荷重端に装着し た 1/1000 mm ダイヤルゲージにより，0.05〜0.25 mm の範囲で適当な間隔で荷重を読み取り, 式（6）を用い て各段階の付着応力を算定し, 付着応力すべり曲線を描 くとともに終局付着強度を求めた.

$$
\tau_{0}=\frac{P}{7 \pi \phi^{2}}
$$

なお，鉄筋のすべりを荷重端で測定した理由は, 自由端 すべり量はせん断ひびわれの発生によって乱されるから である。

\section{（2）異形鉄筋の表面形状が終局付着強度に及ぼす影}

\section{a) ふし間隔の影響}

丸鋼を切削した横ふし形のモデル鉄筋と鉄筋 A のふ しを適宜切除したものについて, 偏心引抜き試験を行っ た. 鉄筋試料はいずれも D 32 であって，モデル鉄筋は ふし間隔 $15.9 \mathrm{~mm}(0.5 \phi), 31.8 \mathrm{~mm}(1 \phi), 47.7 \mathrm{~mm}$ $(1.5 \phi), \quad 63.6 \mathrm{~mm}(2 \phi), \quad 79.5 \mathrm{~mm}(2.5 \phi)$ および $95.4 \mathrm{~mm}(3 \phi)$, ふし高さ $2.2 \mathrm{~mm}$, ふし側面の傾斜角 90 度である. 鉄筋 $\mathrm{A}$ の加工品はふしし間隔 $12.7 \mathrm{~mm}$ $(0.4 \phi), 28.6 \mathrm{~mm}(0.9 \phi)$ および $41.3 \mathrm{~mm}(1.3 \phi)$, ふし高さ $2.2 \mathrm{~mm}$, ふし側面の傾斜角約 54 度である. 試験の結果を図一12に示す。図一12において，ふし間 隔が $2.5 \phi$ 程度まではふし間隔が大となるほど終局付着 強度はほぼ直線的に増加している．この関係は，モデル 鉄筋の場合と鉄筋 $\mathrm{A}$ の加工品の場合とで差異はなく，

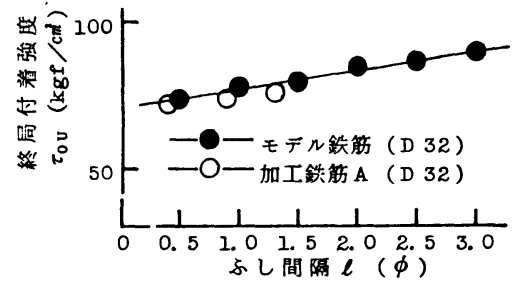

図一12 ふし間隔が終局付着強度に及ぼす影管

ふし間隔 $0.5 \phi$ および $2.5 \phi$ の場合の終局付着強度は約 $73 \mathrm{kgf} / \mathrm{cm}^{2}$ および $88 \mathrm{kgf} / \mathrm{cm}^{2}$ であって, ふし間隔 $0.1 \phi$ の増加により, 終局付着強度は約 $0.8 \mathrm{kgf} / \mathrm{cm}^{2}$ 増大した。

\section{b) ふし高さの影響}

割裂き引抜き試験（3. (2)c）で用いたものと同じ鉄 筋 A の加工品を用い，ふし高さが終局付着強度に及ぼ す影響を検討した。試料鉄筋のふし高さは，0.73 mm， $1.1 \mathrm{~mm}, 1.47 \mathrm{~mm}$ および $2.2 \mathrm{~mm}(0.02 \sim 0.08$ ф)である. 試験の結果を図一13に示す。図一13において，ふし高 さが鉄筋直径の $8 \%$ 程度以下の範囲ではふし高さが高い ほど終局付着強度はほぼ直線的に増大した。

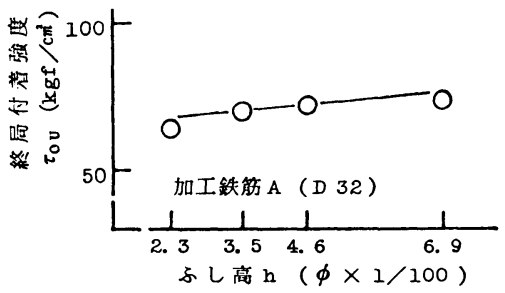

図一13 ふし高が終局付着強度に及ぼす影整

（3）コンクリート強度が終局付着強度に及ほす影零

D 32 の鉄筋 A および D を用い，コンクリートの圧縮 強度を約 $200,250,300,350$ および $400 \mathrm{kgf} / \mathrm{cm}^{2}$ とし た場合の終局付着強度を比較した。試験の結果を図一14 に示す。図一14において，いずれの鉄筋を用いた場合 もコンクリート強度が終局付着強度に及ぼす影響は僅少 であって，たとえば，鉄筋 $\mathrm{A}$ を用いた場合，玨縮強度 約 $200 \mathrm{kgf} / \mathrm{cm}^{2}, 300 \mathrm{kgf} / \mathrm{cm}^{2}$ および $400 \mathrm{kgf} / \mathrm{cm}^{2}$ に対し, 終局付着強度はそれぞれ $69 \mathrm{kgf} / \mathrm{cm}^{2}, 72 \mathrm{kgf} / \mathrm{cm}^{2}$ お び $75 \mathrm{kgf} / \mathrm{cm}^{2}$ となっている.したがって, 式（6）に は圧縮強度に対する補正係数を考慮しないこととした。 なお，（2）および（3）の実験において, 終局付着強 度の変動係数は, $4.3 \sim 8.1 \%$ であった.

\section{（4）通常の引抜き試験方法との比較}

英国規格 ${ }^{10)}$ や日本コンクリート工学協会案 ${ }^{11)}$ (以下 JCI 案と略記）に示されているらせん筋補強コンクリー 卜供試体からの引抜き試験は，それぞれの補強状態に対 応する終局付着強度を試験できる方法として広く利用さ れている.図一15 は, D 32 の鉄筋 A, C およびD を用い,

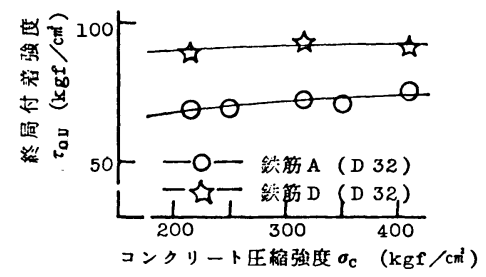

図一14 コンクリート強度と終局付着強度との関係 


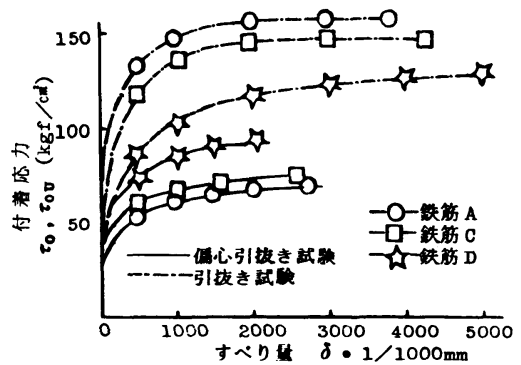

図一15偏心引抜き試験と引抜き試験の付肃応力すべり曲線

偏心引抜き武験と JCI 案の引抜き試験を行った結果で ある. JCI 案の供試体は一辺 $20 \mathrm{~cm}$ の立方形で, 線径 9

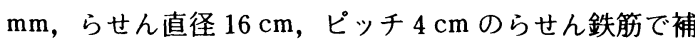
強してある. 図一15において，偏心引抜き試験におけ る終局付着強度は鉄筋 $\mathrm{A} ， \mathrm{C}$ および $\mathrm{D}$ に対して 71 から

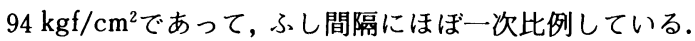
これらに対応する JCI 案の終局付着強度は 158 から 127 $\mathrm{kgf} / \mathrm{cm}^{2}$ であり，ふし間隔が増すほど小となる傾向を示 している．両者が相反する結果となったのは，主として 横方向鉄筋による補強程度の差によるのであって, JCI 案では鉄筋の移動量が大きいものほどコンクリートが押 し広げられ，付着の終局状態に達する以前にコンクリー トの割裂によって破壊したものと考えられる.このよう に，試験方法の相違によって付着強度試験値はもちろん 鉄筋の表面形状に対する付着性能の傾向等も相違する場 合があるから，材料の相対評価としての付着強度を試験 する場合でも試験方法の選定を慎重に行い，誤った判断 とならないよう注意しなければならない。

\section{5. 市販異形鉄筋の付着性状}

従来，ふし形状や間隔を種々に変化させた異形鉄筋の 付着強度を試験し，表面形状の適正化について論じた貴 重な研究がある ${ }^{12), 131}$. しかし, 前記のように, 付着強度 はその試験方法によって著しく相違する場合が多い． 3. および 4. に述べたように，割裂き引抜き試験は鉄筋と コンクリートの一体性を示す初期付着強度, 異形強度の 通常の付着破壊を示す割裂き付着強度，ならびに付着応 力すべり関係に関する情報を与え，偏心引抜き試験は横 方向鉄筋で十分に補強された引張鉄筋の終局付着強度に 関する情報を提供する。そこで，これら 2 つの試験方法 によって, 表一1 に示した横ふし筋 3 種, 斜めふし筋 2 種の市販鉄筋の付着性状を検討した，使用したコンク リートは圧縮強度約 $300 \mathrm{kgf} / \mathrm{cm}^{2}$ のものであり, 付着強 度試験値は供試体 5 個の平均値とした。試験結果を表一 5 に示す．表一 5 には，初期付着強度，割裂き付着強度 および割裂時の自由端すべり量, 終局付着強度および終 局時の荷重端すべり量等が示されている.

\section{表一5 割裂き引抜き試虍㑒および偏心引抜き試験結果}

\begin{tabular}{|c|c|c|c|c|c|c|c|}
\hline 5 & 箭 & 裂 & है 引 & 迶 & 焉 & 偘心引立 & 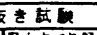 \\
\hline 鉻柄 & 呼区名 & 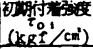 & 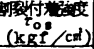 & 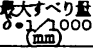 & 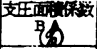 & 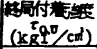 & 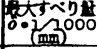 \\
\hline \multirow{8}{*}{ A } & $D 16$ & 66.2 & 128 & 123 & 25.5 & 84.8 & 2100 \\
\hline & D 25 & 74.6 & 126 & 175 & 13.8 & 84.2 & 2500 \\
\hline & D 32 & 72.3 & 121 & 300 & 13.6 & 71.4 & 2600 \\
\hline & D 35 & 89.6 & 126 & 300 & 15.0 & 73.8 & 1800 \\
\hline & D 38 & 87.4 & 120 & 400 & 14.1 & 76. 5 & 1800 \\
\hline & D \&1 & 89.7 & 129 & 400 & 16. 8 & 77.6 & 1900 \\
\hline & D 51 & 98.8 & 123 & 225 & 18.0 & 75. 4 & 1700 \\
\hline & D 57 & 83.3 & 103 & 200 & 26.6 & 69.1 & 1300 \\
\hline \multirow{5}{*}{ B } & D 32 & 53.2 & 124 & 300 & 127 & 80.8 & 4000 \\
\hline & D 35 & 60.9 & 129 & 400 & 5.8 & 82.6 & 3500 \\
\hline & D 38 & 69.6 & 126 & 350 & 7.1 & 88.5 & 3100 \\
\hline & D 41 & 62. 3 & 135 & 450 & 6. 6 & 84.2 & 2900 \\
\hline & D 51 & 97.6 & 125 & 200 & 19. 7 & 82.4 & 2600 \\
\hline \multirow{4}{*}{ c } & D 32 & 83.5 & 129 & 300 & 10.8 & 76.3 & 2000 \\
\hline & D 35 & 87.7 & 113 & 325 & 14.3 & 73. 1 & 2700 \\
\hline & D 38 & 88. 2 & 118 & 330 & 15. 7 & 75.9 & 2800 \\
\hline & D 51 & 91.8 & 114 & 255 & 17.9 & 80.8 & 2600 \\
\hline \multirow{7}{*}{ D } & D16 & 50.2 & 104 & 400 & 13.3 & 88.6 & 1800 \\
\hline & D25 & 64.8 & 120 & 350 & 12.6 & 91.7 & 1700 \\
\hline & $D 32$ & 53.0 & 123 & 475 & 10.3 & 94.1 & 2900 \\
\hline & D 35 & 54.1 & 124 & 500 & 9.3 & 89.4 & 2150 \\
\hline & D 38 & 58. 7 & 128 & 400 & 9.2 & 87.3 & 2500 \\
\hline & D 41 & 57.2 & 121 & 375 & 13.2 & 92.6 & 2150 \\
\hline & D 51 & 66.1 & 119 & 300 & 13.8 & 93.1 & 1500 \\
\hline \multirow{5}{*}{$\mathbf{E}$} & D 32 & 61.6 & 125 & 350 & 11.5 & 72.4 & 3200 \\
\hline & D 35 & 57.2 & 134 & 400 & 9.8 & 71.1 & 3400 \\
\hline & D 38 & 57.4 & 129 & 550 & 8. 9 & 73.4 & 3500 \\
\hline & D 41 & 57. 9 & 120 & 500 & 8. 6 & 73. 9 & 2700 \\
\hline & D 51 & 72.6 & 121 & 400 & 12.5 & 72.3 & 2200 \\
\hline
\end{tabular}

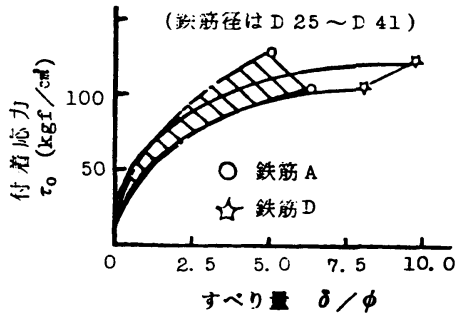

図一16 付苇応力すべり曲線

a) 付着応力すべり関係

図一16 は鉄筋 $\mathrm{A}$ および $\mathrm{D}$ の割裂き引抜き試験結果に ついて, 鉄筋直径で除して無次元化したすべり量 $(\delta / \phi)$ と付着応力との関係を示したものである. ふし間隔を直 径にかかわらず一定とした鉄筋 A の付着応力すべり曲 線は，直径によって分散するが，ふし間隔が直径に比例 する鉄筋 D の場合はほぼ一曲線に収斂している。これ は，引抜きによって鉄筋周囲に内部ひびわれが発生し， 用性の低下した層が形成され，鉄筋の表面形状が幾何学 的に相似の場合，その厚さが鉄筋直径に比例するからで あろう。したがって，このように相似の表面形状を有す る異形鉄筋の場合には，代表的な直径の鉄筋について割 裂き引抜き試験を行えば，他の直径の鉄筋の付着性状を 類推することができる.

b) 付着性状の一般的傾向

図一17は，横ふし筋と斜めふし筋の割裂き引抜き試 験および偏心引抜き試験における典型的な付着応力すべ り関係であって, D 32 の鉄筋 A および D の場合である. 


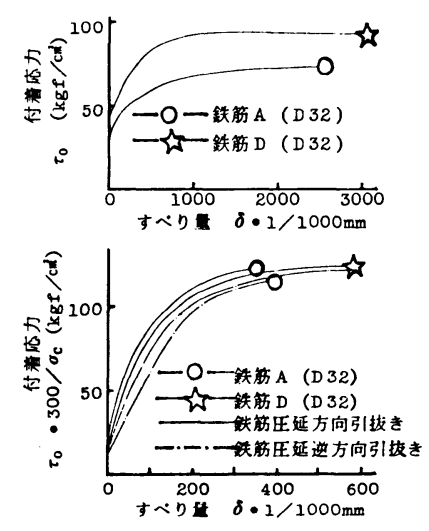

図一17割裂き引抜き試験および偏心引抜き試験 における典型的な付苇応力すべり曲線

ふしの間隔，高さおよび側面の傾斜角の相違により，割 裂き引抜き試験における付着応力すべり曲線の勾配は著 しく相違し，鉄筋 A の初期付着強度は鉄筋 D の約 1.4 倍となり，一体性に優れていることを示している．しか し，いずれの鉄筋もふし間隔が直径の $70 \%$ 以下，ふし 側面の傾斜角は 45 度以上であるため, 割裂き付着強度 に差異はない，また，鉄筋 D の割裂き時の自由端すべ り量は鉄筋 A の約 1.6 倍であって, 割裂き破壊に対し て粘りのある性状を示し, さらに鉄筋 D の終局付着強 度（上図）は，鉄筋 A より約 $30 \%$ 大きい．ふし側面 の傾斜角は圧延方向と反対方向とで相違する.すなわち， 鉄筋 A の圧延方向の傾斜角 54.3 度, 反対方向 56.7 度, 鉄筋 D の場合, 圧延方向 43.8 度, 反対方向 49.9 度で ある. 下図中の一点鎖線は，引抜き試験における荷重方 向と圧延方向を一致させた場合，実線は，相反せた場合 であって, 両者の割裂き付着強度に差異はないが, 付着 応力すべり曲線の勾配は相違し，圧延方向に引いた場合 の初期付着強度は, 反対方向の約 $0.6 \sim 0.8$ 倍となって いる．したがって，本実験においては，すべて荷重方向 と圧延方向を一致させ，引抜き試験を行ったのである.

c）初期付着強度および割裂き付着強度

初期付着強度は，表一5に示すように，鉄筋の表面形 状によって相当に相違し約 $50 \sim 90 \mathrm{kgf} / \mathrm{cm}^{2}$ となった。

鉄筋の付着性を表わす形状係数として, 従来支圧面積係 数が提案 ${ }^{8}$ されている. 図一18 は支圧面積係数と初期付 着強度との関係を示したもので, 表一5の試験結果だけ でなく，3. (2) に示したモデル鉄筋の試験結果のうち, ふし側面の傾斜角 45 度以上のものも打点してある. 図 中の回帰直線の相関係数は 0.24 であって, 付着性をふ し間隔と高さだけの関数で表わすことは困難のようであ り，現状では適当な試験によって評価するのが望ましい． 次に表一 5 において, 割裂き付着強度は, 一部の太径

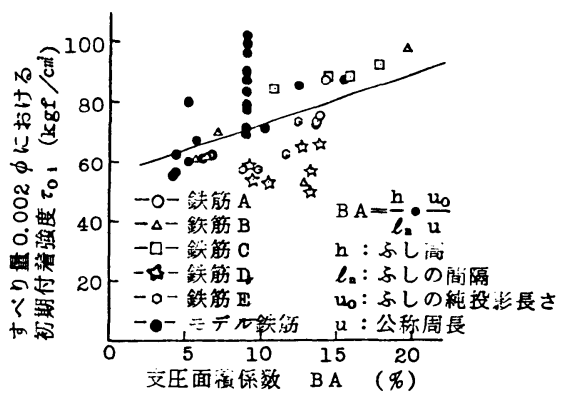

図一-18 支圧面樌係数と初期付着強度との関係

鉄筋を除いて 120 ～ $130 \mathrm{kgf} / \mathrm{cm}^{2}$ とほぼ同様な値を示し ている.これは，試料とした市販鉄筋がすべて JIS G 3112 に適合し，ふし間隔が $0.7 \phi$ 以下であることによ る. 鉄筋 A の D 57 の割裂き付着強度は, 他に比して $20 \mathrm{kgf} / \mathrm{cm}^{2}$ 程度小さい。これは, 同種の鉄筋の D 51 以 下に比へ，ふし側面の傾斜角が著しく小さいこと等によ ると思われる.

d）終局付着強度

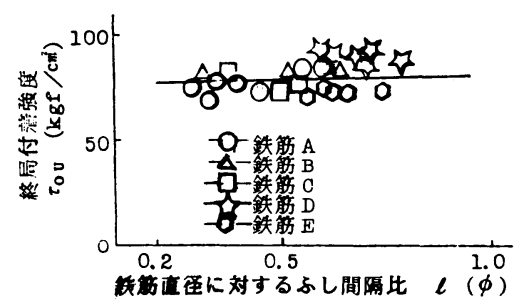

図一19 ふし間隔と終局付兼強度との関係

図一19は，表一5に示すすべての試験値について，終 局付着強度を鉄筋直径に対する比で表わしたふし間隔に ついて整理したもので，図一12に示したD 32 のモデル 鉄筋の試験結果を実線で記入してある. 図一19におい て, 圧縮強度約 $300 \mathrm{kgf} / \mathrm{cm}^{2}$ のコンクリートを用いた場 合の終局付着強度は約 $69 \sim 94 \mathrm{kgf} / \mathrm{cm}^{2}$ の範囲であり， ふし間隔比が大きいほど終局付着強度が大となる一般的 傾向が示され，大部分の試験値は，モデル鉄筋の結果と 近似している。

\section{6. 結 語}

異形鉄筋の付着破壊の性状に類似させることを主眼と した割裂き引抜き試験方法および偏心引抜き試験方法を 提案し, 異形鉄筋の表面形状およびコンクリート強度が 付着強度に及ぼす影響を確かめ, さらに, 市眅の異形鉄 筋の付着特性を明らかにしたこの実験の範囲内で次のこ とがいえると思われる。

（1）割裂き引抜き試験は，異形鉄筋のふしのくさび 
作用によるかぶりコンクリートの割裂き破壊を表現する ため, 無筋コンクリート供試体からの引抜き試験として おり，割裂き付着強度のほか，一体性を表わす初期付着 強度ならびに付着応力すべり関係に関する情報を与え る。また，偏心引抜き試験は，はりのせん断スパン部を モデル化した供試体において, 横方向鉄筋で十分補強さ れた引張鉄筋の引抜きによるふし間コンクリートのせん 断破壊を表現し, 終局付着強度に関する情報を提供する. これらの方法における試験誤差は小さく, 割裂き付着強 度の変動係数で約 $7 \%$, 終局付着強度の場合, 約 $6 \%$ で あった。

（2）かぶりと鉄筋直径との比が一定である場合，割 裂き付着強度は理論上ふし側面の傾斜角の正切とコンク リートの引張強度に正比例するが，実験結果は，ふし側 面の傾斜角が大になると支圧によって押し固められたふ し前面のモルタルがゆるい斜面をもつ仮想のふしを形成 するため，傾斜角が 45 度程度以上では割裂き付着強度 はほぼ一定值を示す。したがって，異形鉄筋の軸線を含 む面におけるふし側面の傾斜角は 45 度以上とするのが よい.

（3）割裂き付着強度はふし間隔が鉄筋直径以下の範 囲ではふし間隔にかかわらずぼ一定值を示すが，これ を超えるとしだいに低下した，また，ふし高さが鉄筋直 径の 7 - 8\% 以下の範囲では, 割裂き付着強度はふしし高 さに比例して増加する傾向を示した。

（4）終局付着強度は，ふし間隔が鉄筋直径の約 2.5 倍まではふし間隔が増すほどほぼ直線的に増大し，その 増大する程度は，ふし間隔が鉄筋直径の $0.5 \sim 2.5$ 倍ま でに約 $20 \%$ であった。また，終局付着強度はふし高さ に伴って比例的に増加し，ふし高さが鉄筋直径の 2 8 $\%$ の範囲で終局付着強度の増加は約 $14 \%$ であった。

（3）および（4）の結果から，異形鉄筋のふしの間隔 は鉄筋直径以下とし，3しの高さは鉄筋直径の約 7 8 $\%$ 程度とするのがよい.

（5）割裂き付着強度はコンクリート強度の影響を顕 著に受けるが, 終局付着強度の場合その影響は少ない. すなわち, 圧縮強度 $200 \sim 400 \mathrm{kgf} / \mathrm{cm}^{2}$ の範囲で割裂き 付着強度は 98 $218 \mathrm{kgf} / \mathrm{cm}^{2}$ と圧縮強度にほぼ一次比例 するが，終局付着強度の差異はごく少なく $5 \mathrm{kgf} / \mathrm{cm}^{2}$ 程 度であった。

（6）市販の異形鉄筋はふしの間隔および高さが鉄筋 直径に比例するものが多い。このような場合, 割裂き引 抜き試験で得られる付着応力すべり曲線において，すべ り量を鉄筋直径で除して無次元化した場合, 鉄筋直径に かかわらずほぼ一曲線に収斂する．したがって，代表的 な直径の鉄筋について割裂き試験を行えば，他の直径の 付着性状を類推することができる。ただし，ふし側面の
傾斜角が製造時の圧延方向と反対方向とで相違し，これ が付着応力すべり曲線の初期の勾配に相当に影響するの で注意しなければならない。

（７）市販の異形鉄筋は横了し型と斜めふし型に大別 され，これらの付着性状は（2），（3）および（4）で 述べた法則によって説明されるが，およそ次の一般的傾 向が認められた。横ふし筋はふし側面の傾斜角が大きい ので初期付着強度が大で一体性に優れているが, 割裂き 破壊時のすべり量は小さい。いずれの鉄筋のふし間隔も 直径の $70 \%$ 以下となっているので, 割裂き付着強度に 差異はないが，終局付着強度はふし間隔および高さが大 きいものほど大となった。

（８）コンクリートの圧縮強度約 $300 \mathrm{kgf} / \mathrm{cm}^{2}$ の場 合, 市販の異形鉄筋の初期付着強度は鉄筋の表面形状に より $50 \sim 92 \mathrm{kgf} / \mathrm{cm}^{2}$ と大幅に変化したが, 割裂き付着 強度は一部の太径鉄筋を除いてほぼ一定値を示し，120 〜 $130 \mathrm{kgf} / \mathrm{cm}^{2}$ であった。 また，終局付着強度はふし間 隔および高さにより $63 〜 90 \mathrm{kgf} / \mathrm{cm}^{2}$ であった。

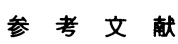

1) Anders Losberg and Per-Ảke Olsson : Bond Failure of Deformed Reinforcing Bars Based on the Longitudinal Splitting Effect of the Bars, ACI Journal, January 1979.

2）森田・角：太径鉄筋 “D 51” の割裂き強度，コンクリー 卜工学, Vol. 16, No. 10, Oct. 1978.

3) ASTM Designation C 234 : Standard Test Method for Comparing Concrete on the Basis the Bond Developed with Reinforcing Steel.

4) RILEM Recommendation 7-11-28 "Bond Test for Reinforcing Steel” 2, Pull-Out Test.

5）大塚・佐藤・加藤：引張異形鉄筋周辺のコンクリートの 縦ひび割れについて, 土木学会東北支部大会, 昭和 51 年.

6) Leroy A. Lutz and Peter Gergely : Mechanics of Bond and Slip of Deformed Bars in Concrete ACI Journal, Nov. 1967.

7) Rehm, G. : The Fundamental Law of Bond Proceeding Symposium on Bond Crack Formation in Reinforced Concrete. Stockholm 1957.

8）国分・岡村：太径鉄筋の使用に関する研究，土木学会論 文報告集，第 202 号，1972 年 6 月.

9) RILEM Recommendation 7-11-28 Bond Test for Reinforcing Steel I. Beam Test.

10) B.S. Code of Practice for Reinforced Concrete CP $114,1972$.

11）日本コンクリート工学協会, 鉄筋とコンクリートの付着 強度試験方法案，土木材料実験，技報堂， 1982 .

12）国分・岡村：コンクリートと補強材との結合機構に及ぼ す補強材の表面形状の影響, 第 6 回複合材料シンポジゥ 么, 日本科学技術連盟，昭和 48 年 10 月.

13) George Robert Wernish: Bond Studies of Different Types of Reinforcing Bars, Journal of ACI, Vol. 34, 1937

(1984.12.13 • 受付) 